\title{
Transformation of Sexual and Matrimonial Behavior of Tajik Labour Migrants in Russia
}

\author{
Sergey V. Ryazantsev ${ }^{1}$, Elena E. Pismennaya ${ }^{1}$, Irina S. Karabulatova ${ }^{2} \&$ Sharif Y. Akramov $^{1}$ \\ ${ }^{1}$ Institute of Social and Political Research, Russian Academy of Sciences, Russian Federation \\ ${ }^{2}$ Kazan Federal University, Tatarstan str. 2, Kazan, Russian Federation \\ Correspondence: Sergey V. Riazantsev, Leninsky Prospect 32a, Moscow, 119991, Russian Federation. E-mail: \\ riazan@mail.ru
}

Received: June 20, 2014 Accepted: July 16, 2014 Online Published: September 28, 2014

doi:10.5539/ass.v10n20p174

URL: http://dx.doi.org/10.5539/ass.v10n20p174

\begin{abstract}
This research targets at revealing the influence of labor migration on the transformation of family relations, sexual and matrimonial behavior of the Tajikistan population. Tajikistan is one of the countries that are best known for their active sending labor migrants abroad to work. The majority of labor migrants work in the Russian Federation. The research included combination of quantitative and qualitative methods, including the statistical method, as well as quantitative sociological polls of migrants and their family members, as well as qualitative interviews of expert and migrants. The qualitative sociological poll was carried out in two countries (Russia and Tajikistan) based on two questionnaires similar by structure and coverage of the studied problems in 2012-2013. The research detected transformation of the family relations, matrimonial mindsets, and sexual behavior of the labor migrants, which affected their families and were able to affect the demographic situation in Tajikistan in the future. Two ways of satisfaction of sexual needs of the labor migrants were revealed. The first way is paid sexual services, i.e. using the services of prostitutes. The second way is a "temporary wife", also known as a "guest marriage". During the research, we registered multiple cases, when Tajik labor migrants had a "temporary wife" in Russia. She is often treated as "temporary" only as they try to keep parallel relations and socio-economic ties with their families and wives in Tajikistan. In fact, extramarital relationship in the form of a "guest"/"temporary" marriage is a form of adaptation of a labor migrant to the new socio-economic environment and is based on the Sharia laws regarding the "temporary" marriage. Tajikistan keeps its traditional mindset for the need in solid family relations and giving birth to 3-5 children. This model of a Muslim marriage is extended by the Tajik migrants to the Russia's reality. Because the Muslim law allows marrying women who practice a monotheistic religion (Christianity, Judaism), Tajiks establish various types of polygamous relations with Russian women. Those can be various types of a Muslim marriage (a temporary or permanent marriage, or a marriage without obligations, or a marriage for entertainment) that are set by Islam. Understanding of the traditional Tajiks' vision of sexual and marital relations provides the opportunity to forecast matrimonial behavior of Tajik migrants in Russia. At the same time, such forms of marriage are not traditional for Russia, which causes mixed response of the main part of the population who are not familiar with the standards of the Muslim moral.
\end{abstract}

Keywords: labor migration, family relations, sexual behavior, matrimonial behavior, Islam, Sharia, Tajikistan, Russia

\section{Introduction}

Tajikistan is one of the countries that are best known for their active sending labor migrants abroad to work. According to our previous researches, there is only one foreigner working in Tajikistan against 400 Tajiks working abroad (Ryazantsev, 2007). The significant growth of labor migration from Tajikistan started in the mid-1990s, when the socio-economic situation in the country became considerably worse forcing many citizens of the republic to seek jobs abroad. It is rather difficult to estimate the number of labor migrants abroad, as there is no precise accounting of labor migration. According to the information of the statistical service of Tajikistan, 420 thousand people worked abroad, more than 413 thousand of them worked in Russia. The real number of labor migrants from Tajikistan is greater. For example, according to the Federal Migration Service, approximately 410 thousand labor migrants from Tajikistan obtained permission for work and patents in 2012 in 
Russia. This is confirmed by the research-according to the investigation of MOM and the Shark Center, the volume of labor migration from Tajikistan was equal to 630 thousand people (Olimova \& Bosk, 2003). According to the 2010 census, over 200 thousand Tajiks domiciled in Russia. But a more realistic estimation of the population of labor migrants from Tajikistan in Russia numbers between 600 thousand and 1 million people. This equals to $26-44 \%$ of the economically active population of the country. According to the World Bank, about 790 thousand citizens of Tajikistan stayed abroad in 2010, which is equal to over $11 \%$ of the country's population (Migration and Remittances..., 2011). Tajik labor migrants work almost in all regions of Russia, but their maximum number is concentrated in megalopolises (Moscow and surroundings, Saint Petersburg) as well as in regions neighboring or located close to Kazakhstan with a high ratio of migrants capacity (the Yekaterinburg/Sverdlovsk, Novosibirsk, Tyumen, Samara, Chelyabinsk, Kemerovo, and Krasnoyarsk regions).

Tajik labor migrants can be broken up to two groups. The first and most numerous one are seasonal workers. Their flow increases in spring and summer, as they go to Russia to work in the agricultural and construction sectors. Those return home in fall. According to approximate estimations, $75-80 \%$ of seasonal migrants in some regions of Russia come from Tajikistan. The second group of Tajik migrants includes those who stay and work in Russia for a long time or almost permanently. They work both legally and without official employment in the construction, service, and housing and utilities sectors, as well as in transport companies. Men prevail among labor migrants from Tajikistan, though since recently, feminization of the migration takes place. The age structure depends on the spheres of employment. There are more young people in the construction sector, as migrants are hired to do the hardest job requiring endurance, physical power and good health condition. The share of middle and senior age people is larger among agricultural and in-house employees, as well as in the housing and communal sector. In ethnic terms, the majority of labor migrants who come from Tajikistan are Tajiks. However, there are a large number of ethnic Uzbeks, too, as over one million ethnic Uzbeks live in the Republic of Tajikistan. According to the researches, the majority of Tajik labor migrants (about 69\%) worked in Russia under a verbal arrangement and only one fourth part of labor migrants sign a written labor agreement. Only 23\% of the responders had permission for working in Russia. Many migrant workers from Tajikistan have very poor working and living conditions (Akramov, 2006; Baizhigitov, 2014). Our previous researches showed that about $40 \%$ of labor migrants worked and lived at the same place. As a rule, those were premises not suitable for living: cellars, basements, unfinished buildings or buildings subject to demolition, waste pits. Such premises often have anti-sanitary conditions, no water, and heating, light, basic utilities. Here, migrant workers cook meal, wash and sleep. People often go ill in such conditions. Many migrants live and work for many years in Moscow, but never leave their yard or district. There was a case when one woman, a citizen of Tajikistan, who worked as a concierge and a street cleaner, gave birth to a child right in the basement (Riazantsev et al., 2010). Such subhuman living conditions of migrant workers not only hinder their integration in the Russian society, but also result in formation of "parallel communities", in which people do not speak Russian, and the local population forms an attitude to them as second grade people. Not to mention that such terrible living conditions humiliate human dignity and harm the health of labor migrants, form their negative attitude to local population and to Russia as a whole. Such a situation can result in ethnic and social conflicts (Karabulatova \& Polivara, 2013; Juraeva, 2014; Yuldashev, 2014; Turdiev, 2012; Pickup, 2003). For the recent years, many Tajikistan citizens have managed to obtain Russian citizenship and possess two passports currently: the Russian and Tajik ones. This fact evidences transformation of the temporary labor migration into the permanent one. Such large-scale labor migration has had considerable consequences for Tajikistan.

The mindset for establishing a "guest marriage" comes from the Islamic culture, in which, according to Koran, it is recommended to enter into temporary relations within the so-called "temporary marriage" (e.g. Orfi-a marriage without obligations, Mutah (Sigheh)-a marriage for entertainment). This type of a marriage can be entered into for a period between one hour and ninety nine lunar years, but it can be re-registered as a permanent marriage, if both spouses wish to do it.

It is to be noted that Tajiks practice Sunni Islam and Sufism, which is also very popular among the Muslims of Central and Middle Asia and Siberia (Foltz, 1996; Jonson, 2006; Sayfulina et al., 2013). However, both Shia and Sunni sources read that the temporary marriage was permitted by the Prophet Mohammad and was widely practiced in the times of reign of the two first Caliphs Abu Bakr and Umar (Muslim, 2007, p. 22). For the first time, this form of marriage was permitted in view of long stay of husbands at wars in order to satisfy men's natural libido. At that, a woman who has entered such a marriage is equalized to a common wife, fulfills all obligations of a married woman and has all rights of a wife. The man has to aliment completely the temporary wife during such a marriage and in case a child is born during the marriage, it will have all rights as a one born within wedlock. At the same time, when such a marriage is terminated, the woman has to wait three months 
before she is allowed to enter into a new marriage. During the temporary marriage, a woman is to be faithful to her husband. As we can see, such a form of a marriage becomes very popular among migrants, lets them satisfy their needs, and also closes the gap of the men's deficiency for Russian women, giving them the impression of normal family relations. This mutually conditioned process contributes to entrenchment of such forms of marriages that are not typical of Russia. Thus, we can state that this mindset for a temporary marriage spreads because of migrations.

Where socio-economic and political consequences of labor migration are studied rather thoroughly in scientific publications, its influence on family relations and sexual and matrimonial behavior of the Tajikistan population has not been studied to a sufficient extent (Kirghizstan asks ...; The data of the Federal Service of State Statistics).

Throughout the research, we noticed cases when labor migrants did not live permanently with their "new" wives, but visited them according to Ayats and Hadises. For example, a Muslim in a temporary marriage cannot avoid sexual relationship with the temporary wife longer than four months, at that; Sharia regulates sexual relationship in a permanent marriage not less than once in four days. A man shares his household with his temporary/"new" wife (she washes his clothes, cooks meal) and has sexual relations, which is prescribed by the Sharia laws. In some cases, these are Russian women from the local population, as Koran allows a Muslim to enter into sexual and marital relations with women of the Great Unified Book (the Bible), i.e. with Muslims, Christians, and Hebrews. Sometimes, such relations transform into closer forms of extramarital relationship and even a marriage. Very common phenomena at such relationships are birth of children, divorce with the previous wife, and a new official marriage. According to the Ja'fari jurisprudence, any temporary wife is a legitimate spouse of a man in Sharia; accordingly, she assumes the obligation to be faithful to her temporary husband during the whole period of the temporary marriage and during 'iddah (two menstrual cycles). However, if a woman being temporarily married commits adultery, the Sharia laws prescribe to punish her as a non-married one (similarly, things go for a man in temporary marriage). At the same time, a child born as a result of a temporary marriage, is legitimate and has equal rights with children born in a permanent marriage. This child has the right for full aliments by the father until he reaches the age, when he will be able to pay way. Despite the spreading phenomenon of a "guest marriage" among Tajik migrants, it has not become a widespread form of relations accepted by the whole Tajik society. It is explained by the fact that the Sunni Islam does not have an unambiguous attitude to the "temporary marriage"; it is rather forbidden than permitted (Muslim, 2007, p. 21).

\section{Research Methodology}

The research included combination of quantitative and qualitative methods, including the statistical method, as well as quantitative sociological polls of migrants and their family members, as well as qualitative interviews of expert and migrants. The qualitative sociological poll was carried out in two countries (Russia and Tajikistan) based on two questionnaires similar by structure and coverage of the studied problems in 2012-2013. The poll was carried out in the Russian, Tajik, and Uzbek languages. The first questionnaire "Tajik migrants: the family and the reproductive health" contained 44 questions and targeted Tajikistan citizens (mainly men) who at the time of the poll were officially married or had extramarital relations and had a spouse residing in Tajikistan. 214 responders were interrogated in Moscow and the Moscow region. The sampling was representative by three attributes (the sex, the age, and the sphere of employment of the migrants in Russia) and was compiled based on the data of the Federal Migration Service of Russia by the socio-demographic structure and spheres of employment of the Tajikistan citizens who obtained permission for working in Russia in 2011. In order to ensure the representativeness, we used quota-based sampling by the economic sectors. The second questionnaire "A Tajik family and labor migration" included 50 questions and focused on the Tajikistan citizens (mainly women) who at the time of the poll domiciled in Tajikistan, were officially married or had extramarital relationship, or whose spouse had recently worked (during the year precedent to the poll) or was working at the time of the poll in Russia. Based on this questionnaire, 186 responders were interrogated in various regions of Tajikistan. We used random sampling, as there was no precise data on the socio-demographic structure of households, which had labor migrants, in Tajikistan. The sampling was random, the validity was provided for by selection of the responders in various types of settlements and by wide geography of the poll. For a more detailed analysis, the data of many questions were matched for the two groups of the responders, which allowed obtaining more impersonalized information with regard to the influence of the labor migration on the family relations in Tajikistan based on the opinion of the two parties: the labor migrants in Russia and their spouses (wives and husbands) who stayed in Tajikistan.

The qualitative sociological poll was represented by in-depth interviews with labor migrants who were selected in the course of a quantitative sociological poll based on the information on new relations and sexual partners in 
Russia. Those responders were exposed to in-depth interviews targeting studying the phenomenon of the "parallel" or "guest" marriage. Totally, 25 men and women from Tajikistan working in Russia gave in-depth interviews. Also, 20 experts were interviewed, namely representatives of organizations dealing with labor migrants from Tajikistan (employees of non-governmental organizations, lawyers, trade union leaders, etc.).

The statistical method allowed matching the data of the official statistics of the countries sending and receiving Tajik labor migrants. In Tajikistan, the data are the results of accounting of citizens going abroad based on the migration accounting cards filled in by them. In the Russian Federation, the data include information on the number of permissions for work and patents issued to the citizens of Tajikistan as well as information on the socio-demographic structure of the migrants who have obtained permissible documents to work in Russia. Also, the statistical estimates of labor migration and money transfers of the labor migrants were involved, which are made by international organizations (the World Bank, the International Migration Organization).

\section{Research Results}

The research showed that, as a rule, labor migrants stayed away from their wives and families for a long time. Spouses came only to $10 \%$ of labor migrants while they were working in Russia, because it is rather expensive. Labor migrants go to Tajikistan from Russia only once a year. If they are seasonal workers, it usually takes place in winter when there is temporary recession in the agricultural and construction sectors.

The research detected transformation of the family relations, matrimonial mindsets, and sexual behavior of the labor migrants, which affected their families and were able to affect the demographic situation in Tajikistan in the future. First of all, it is the use of means of contraception. 9\% of labor migrants in Russia and $21 \%$ of their partners in Tajikistan use them permanently. Besides, $40 \%$ of labor migrants and $24 \%$ of their partners in Tajikistan rather used than did not use means of contraception. This evidences awareness of labor migrants and members of their families in the sphere of sexual knowledge and sexual behavior. However, an interesting fact is that approximately half of the interrogated Tajik labor migrants in Russia had sexual relations with other partners other than their wives (husbands). At that, $13 \%$ of the responders had sexual contacts with other partners (other than their spouses) quite often! And just $52 \%$ of the responders did not have extramarital sexual contacts during their work in Russia. This is a revolutionary shift of sexual behavior of Tajiks, or at least of those who were involved in labor migration.

We can identify two ways of satisfaction of sexual needs of labor migrants. The first way is paid sexual services, i.e. using the services of prostitutes. The responders noticed that the practice is very popular when a call girl is invited for a group of workers in order to save money. In Moscow, this type of services is of high demand and is sometimes used by employers as an incentive for the workers. According to the poll, $35 \%$ of labor migrants had used this method of libido satisfaction. The second way is a "temporary wife", also known as a "guest marriage". This phenomenon is widely spread because of mass labor migration, is nevertheless based on the Sharia laws. Like at a permanent marriage procedure, a special marriage formula is read for legitimization of marital relations, and the difference of the formula from the formula of a permanent marriage is only specification of the marriage term. After the term of the temporary marriage expires, the man and the woman can extend it for any term and as many times as they wish. Besides, they can enter into a permanent marriage instead of a new temporary marriage. According to certain incompetent statements, a temporary marriage is legalized prostitution. However, such opinion is erroneous as there are the above-mentioned obligations of the woman (such as inadmissibility of adultery and the necessity of waiting for the expiration of 'iddah) and of the man (the child support). The overwhelming majority of Shia mujtahids forbid temporary marriage with prostitutes. As the Islamic laws permit temporary marriages and polygamy (it is allowed to marry 4 women, provided the man provides each of them with aliments and separate accommodation), new forms of marriage appear in the circumstances of Russia, which are brought from the Tajik Islamic reality.

Male labor migrants create parallel families or extramarital relations with Russian women or female migrants. Often, the former family slowly decays. A "guest marriage" is a relatively new socio-demographic phenomenon for Tajikistan, as the Sunni tradition does not unambiguously treat such temporary marriages, where the Shia tradition believes them definitely permitted. This admissible interpretation of the "temporary marriage" in Sharia literature has allowed its popularization among labor migrants. The contemporary scientific literature does not have a uniform approach to the issue of guest marriages. A "guest marriage" is understood by the majority of sociologists more as a state of necessity of a human, rather than a free choice (Bock, 2005). According to another definition, "guest marriages" are states when people keep strong stable relations (including the sexual ones), spend most time together, and have few differences from a married couple, except for the fact that they live apart from each other and do not register their relations officially. For example, before starting a "guest marriage", 
many responders had lived in common (traditional) families. However, many researchers when mentioning a "guest marriage" emphasizes that the official registration of the spouses' relations is also possible, which is normal for the Muslim society governed by the Sharia law.

Two factors are the ground for "guest marriages" among labor migrants. Firstly, there are cases of polygamy in Tajikistan, when well-off men unofficially and actually have several wives, which is however contradictory to the official secular legislation, but permitted by the Islamic laws. The Tirmidhi's collection also contains Hadis about the position of Abdullah ibn Umar, the son of Umar ibn Al-Khattāb: "One man asked Abdullah ibn Umar about the temporary marriage during Hajj, and he answered: "It is allowed (halal)". Then, he was asked: "But your father forbade that". He said, "Do you think my father could forbid what the Prophet had done? Do I have to follow the words of my father or the words of the Prophet?" The man answered: "Of course, the words of the Prophet (Tirmidhi, 2010, p. 56). Koran interpreters are convinced that the prohibition for temporary marriage in some cases depended on the situation and was not permanent (for example, the Prophet Muhammad did not permit warriors enter into a temporary marriage during some key battles to prevent anything from interrupting the warriors from the war). Currently, polygamy in the Tajik society is a very popular phenomenon, it is accepted by the society and, thus, forms potential ground for change of the partner and a "guest marriage" during migration. Migration is just a stimulus for implementation of this potential.

Secondly, often in the circumstances of migration, the husband and the wife live separately even when both of them are in Russia. They have to live separately, as it is very expensive to rent an apartment in Moscow for a family couple; one has to pay between 25 and 40 thousand per month. And labor migrants often rent an apartment for 5-10 persons, which is much cheaper. This actually creates objective prerequisites for breach in relations between the spouses and forces them to look for a new partner. According to the Sharia law, absence of sexual relations between spouses for three and more months is a reason for divorce.

During the research, multiple cases were recorded, when Tajik labor migrants had a "temporary wife" in Russia. She is often treated as "temporary" only, as they try to keep parallel relations and socio-economic ties with their families and wives in Tajikistan. But in fact, such extramarital relationship is a form of adaptation of a labor migrant to the new socio-economic circumstances, which nonetheless are permitted by the Sharia law. Throughout the research, we noticed multiple cases, when labor migrants did not live permanently with their "new" wives, but visited them. This also points at the abidance by the Muslim standards of marital relations. It often happens that a Tajik man completely shares the whole household with the new wife (who is usually a Russian). These relations show a tendency of transforming into a common permanent marriage. Solid relations in a temporary marriage assure the Russian woman in her sexual partner to such an extent that she agrees to give birth to mutual children, consolidation of the relations in the family, which results in divorce with the former wife and entering into a new official marriage. Further, we provide several life stories of responders.

Interview with migrant \#1. Shakhlo, a citizen of Tajikistan, ethnic Tajik female, 47 years old, has stayed in Russia for 13 years. She works as a cook at a hot shop in Moscow. During the initial years, she stayed in Russia with her husband who worked in a construction company. They lived separately and met sometimes. After Anvar failed to succeed at work, he left for Dushanbe. Shakhlo has lived for 9 years without her husband in Moscow already, and she goes every year for one month to Tajikistan. Anvar earns very little, the money is not sufficient. In fact, Shakhlo maintains the family and supports her children. The spouses have three daughters. Besides, the woman pays out the family debt. Shakhlo has a man in Moscow, with whom she does not live but meets him sometimes and has sexual relations. Her husband Anvar accepts such a situation. Shakhlo has to tolerate her husband and condemnation by people, her relatives in order to save the family and not to divorce.

Interview with migrant \#2. Kirom, a citizen of Tajikistan, ethnic Tajik male, 50 years old, has stayed in Moscow for approximately 17 years, sells dry fruits. His wife and three children are in Tajikistan. Kirom comes home once a year for 2-3 months and works the rest of the year in Moscow. In fact, Kirom comes home as a guest. His wife got used to this situation long ago. Actually, Kirom "buys" "freedom" from family relations by sending money to his wife from Moscow. Kirom has sexual relations in Moscow with a woman from Uzbekistan. They were even wedded by a mullah there. They meet two-three times a month at the apartment that she rents or at other different places in Moscow. This is a typical "guest marriage".

Interview with migrant \#3. Khilol, a citizen of Tajikistan, an ethnic Tajik male, 57 years old, worked as a chemistry teacher at school. Now, he is in Moscow. During his 16-year stay in Russia, he has changed several professions and occupations: he has worked at a construction company, an advertising manager, and now works as a taxi driver. When he lived in Tajikistan, he had a business but went bankrupt, ran into a large debt. Now, he does not almost help his family. His wife works as a teacher and parents three children. Khilol has a woman in 
Moscow who he has been meeting for more than 5 years by now. He has sexual relations with the woman, but he does not intend to divorce his official wife in Tajikistan.

Interview with migrant \#4. Komila, a citizen of Tajikistan, an ethnic Tajik female, 47 years old. She has worked for approximately 9 years in Moscow, and now she sells vegetables and fruits. Once a year, she comes to Tajikistan for 1.5-2 months. Her husband Rustam works as a cook at Khujand, Tajikistan. His salary is only enough to buy food. They have four children; three sons are already married, as well as their daughter. Kamila earns much more than her husband does. In fact, the money she has earned allowed them to purchase a car, arrange the weddings of their children, pay for the apartment repair, etc. Kamila had a man in Moscow whom she met for several years. But they have parted.

At the same time, Tajikistan keeps its traditional mindsets for the need in solid family relations and giving birth to 3-5 children. Our research shows that labor migration seriously transforms the matrimonial behavior of the part of Tajiks who are involved in labor migration replacing it with freer sexual behavior.

The research has detected the destructive effect of labor migration on family relations in households, the representatives of which are involved in the migration. Particularly, $12 \%$ of responders in Tajikistan noticed that they suspected or assumed that their spouses have extramarital relations in Moscow. One fifth of them are strongly set to divorce in case of adultery. $60 \%$ of the families in case of long absence of one of the spouses faced misunderstanding and psychological problems in family relations. One in six families faced new diseases, which people associated with the absence of one of the spouses or his departure abroad for temporary work, and $9 \%$ of the families faced disease recurrence. $13 \%$ of the families faced more frequent conflicts and quarrels resulting from the long absence of a spouse. Approximately 3\% of the responders named other problems that arose because of long absence of one of the spouses due to the reason of labor migration to Russia. In the course of the sociological poll, we identified key problems that the second spouse who stays in Tajikistan faces in the situation of labor migration of his/her spouse. Approximately half (more than 45\%) of the responders said the main cause was the absence of psychological contact, care and moral support of the absent spouse. About $40 \%$ of partners in Tajikistan faced problems at parenting their children, and $32 \%$ of partners-at household management. Approximately 12\% faced problems associated with the absence of regular sexual relations with their spouses who worked in Russia. Thus, we can state that the main factor of disruptiveness in relations of Tajik families is the moral and psychological circumstances, which destroy the traditional understanding of the role of spouses and the peculiarities of families operation.

\section{Discussion of the Problem}

The data related to the state of health of labor migrants are not full, rather patchy, and are not published on a regular basis. However, the research shows that the problem is the state of health of the labor migrants and their ownership of medical insurance and access to medical services. Labor migrants have been included in the risk group in terms of proliferation of multiple infectious diseases, including diseases of the reproductive system and sexual diseases (Yoo, 2011; How to arrange and protect labor migrants in agriculture and related sectors, 2014; Olimova \& Bosk, 2003; Turdiev, 2013).

The control of the state of health of labor migrants at employment has not been mandatory for all categories of migrants. For example, when obtaining work permission, migrants were required to pass medical examination, but for those who were obtaining a patent for working for an individual it were not necessary. Further, the control over the state of migrants' health becomes weaker, employers do not provide them with medical insurance, and migrants do not pass annual medical examination. According to previous researches, despite the fact that $89 \%$ of migrants in the housing and utilities sector passed medical examination at employment, less than $1 \%$ of the migrant workers in Russia had medical insurance arranged by the employer (Ryazantsev, 2010). Only since 2014 , purchasing medical insurance for those obtaining patents for working in Russia has become mandatory. Still, it is hard to say whether this will improve the situation with migrants' health in the circumstances of absence of a well-arranged system of medical services for migrants. Besides, employers are not interested in medical insurance of their employees and reinforcement of their health.

Interview with expert \#1. A representative of the Medical Center of the Kirghiz expatriate community. Here, no one asks for a medical document when obtaining a patent. When one purchases a work permit, one of the requirements is to provide a medical certificate. You know well that any individual employer can see if a person is ill or suffers some disease, especially if the person lives in the same house or apartment. It can be revealed very quickly.

Interview with expert \#2. A coordinator of the project "Protection of Rights of Labor Migrants" of the Civil Assistance Committee. Migrants do not pass medical examination. This is negligence. An individual for whom a 
migrant works is assumed to control and assist in medical services. But it is a mere nonentity. I will hardly ask a bricklayer whom I invite for tiling my kitchen whether he has medical certificates or insurance. It turns out that these migrants are not at all related to the medical sphere.

Interview with expert \#3. An independent lawyer. Those who work under patents and work permissions do not pass medical examination. They buy fake certificates. Medical examination must not even be passed in Russia, because even if it is passed... I am a labor migrant myself; I have passed this examination multiple times. Do you know how a drug therapist checks whether one is a drug addict or not? They just ask, "Do you drink alcohol? Do you smoke? Show your elbows!" What a raving nonsense it is! Medical examination is not related to migrants. And what is done does not have anything in common with medical examinations.

Interview with expert \#4. A lawyer at the ANA Company. Migrants pass medical examination very rarely. Usually, it is arranged by intermediates. And when a patent is issued, the migrant does not require any medical insurance.

In the circumstances of absence of medical insurance, migrants have to practice self-treatment, look for medical acquaintances, go to pay hospitals. The issues of medical servicing of migrants can be admitted a total failure of the Russian migration legislation. Further, we provide several examples from interviews.

Interview with expert \#5. A representative of a migrants' trade union. Currently, labor migrants are not required to pass medical examination. But each employer can ask a migrant to pass medical examination in order to understand his health state. I think it is one of the deficiencies of the patent system. For example, if today migrants come to Russia, they have to obtain medical insurance policy by themselves. Therefore, labor migrants are not protected currently, as they can only go to private pay hospitals and pay certain amount of money.

Interview with expert \#6. A coordinator of the project "Protection of Rights of Labor Migrants" of the Civil Assistance Committee. They do not do anything. Migrants do not go to doctor. When they are very sick and come to us, we immediately call for an ambulance. Some of them even don't know how to call for an ambulance using a mobile phone. Some of them think they have no right for an ambulance. It is hardly related to the patent, it is related to the overall poor literacy of people. They either treat themselves or neglect any treatment. And when they come to clinics, they are told everything what people think of them. Same story with work permissions.

Interview with expert \#7. An independent lawyer. Migrants either go to their doctors, or call me and I direct them to my doctors. Also, they call any organizations that provide more or less help to migrants, which direct them to their doctors. Unfortunately, there is no other way. In case of emergency, I can call for an ambulance and force them to admit a person to hospital. But it is the best I can do.

Interview with expert \#8. Deputy Head for General Issues of the International Migration Center. Migrants do not pass medical examination. Migrants visit pay doctors. The Center of Kirghiz Migration has established a hospital for migrants. They can go there.

Women suffer from these issues most. Services for pregnant female labor migrants in Russia remain a big problem. This issue has become urgent because of refusal of the Ministry of Public Health and Social Development of Russia to render services to foreign citizens at Russian medical institutions. At the same time, we believe that ensuring medical services for pregnant female migrants would positively influence on the demographic situation in Russia, as children born in Russia could immediately become citizens of Russia by the "right of land".

Interview with expert \#9. A lawyer at the ANA Company. People visit pay clinics. Because since 2010 or 2009 , the Ministry of healthcare refused to help migrants. Even pregnant women. Before, they had assigned pregnant female foreigners. They passed medical examination at polyclinics. And also delivered at hospitals. Now, this practice is gone. If a foreigner wants to pass examination and deliver, it means she needs to go to a pay clinic. Absolutely everything is commercial.

A specific problem of Russia is exploitation of female migrants from Central Asia countries, including Tajikistan. According to official statistics of the Federal Migration Service of Russia, the share of women among foreign citizens who had effective work permission in 2011 equaled to 14\%. The largest share of female migrants (about $18 \%$ ) includes the 30-39 year-old age group. It needs to be noted that lately, the share of women in the flow of labor migrants from the Central Asia countries to Russia has been increasing. Women's labor is very popular in the retail and services and agricultural sector's and in households. The peculiar feature of labor exploitation of female migrants is that it is often combined with sexual abuse and violence. Women can be enslaved, exposed to sexual harassment and sexual discrimination. Women face greater difficulties at finding a job. They also more often go to a compatriot who has worked here for a longer period. But women also more often get into slavery, 
sexual slavery, and are exploited. It is not infrequent that they get pregnant, and such women cannot get another job.

Interview with expert \#10. A project coordinator at an NGO. Women face greater difficulties at finding a job. They also more often go to a compatriot who has worked here for a longer period. But women also more often get into slavery, sexual slavery, and are exploited. It is not infrequent that they get pregnant. They cannot work if they have a child. Because of the child, they cannot work and fail to provide for themselves and the child. Our committee helps such women to return home, where they have parents, not to let them die of hunger here in Russia. For such women, the door to work is closed.

Interview with expert \#11. Deputy Head of a migration center I cannot ignore the problem of human trafficking. We have many complaints when some bad people bring migrants from Central Asia and sell them. Two months ago, I had a call from relatives of a woman, Akhmedova Sh.B. Her brother said that his sister died in the Chekhov district. On the same day, I invited the Mir TV Company and went to the Chekhov district. We visited the morgue and hospitals and studied the issue. We spoke to all doctors and shot the whole process with a hidden camera. We tried to find out who gave the referral and sent her to the hospital. She did not even have documents and did not know the Russian language. When she came, she was promised a 1,000-dollar salary and was invited to work. It turned out that she was sold to an accommodation house. With the help of law-enforcement agencies, we found a woman who brought her by deceit and sold her to the accommodation house. And this 25-year-old girl died. I can even give you the CD, which we shot in the Chekhov district.

The results of the sociological poll evidence that $9 \%$ of Tajik labor migrants in Russia have suffered venereal diseases during the past three years, and the members of their families in Tajikistan-in more than $11 \%$ of cases. According to the results of the poll of labor migrants in Russia, 38\% of them have visited a doctor with problems of reproductive health lately. And appeal ability of the spouses in Tajikistan was lower and equaled to $23 \%$ of the responders. This fact evidences that the problems of the reproductive health are an urgent issue for Tajik labor migrants. It is obvious that the diseases recrudesce due to the change of their sexual behavior.

Thus, the state of health and the issues of medical examination are important for labor migrants who come to another climate and social conditions; they can even be unaware of the diseases they suffer. At the same time, their organisms can differently respond to the new living conditions. Therefore, medical examination of migrants working in Russia must be a necessary element of the system of registration and utilization of expatriate workforce. All the above-listed trends result in the loss of health and reproductive health by the labor migrants from Tajikistan who work in Russia. This can have negative consequences in terms of increase in morbidity and mortality, decrease in the birth rate in Tajikistan itself in the long view.

\section{Conclusion}

The fulfilled research documents precisely the tendency of considerable transformation of matrimonial mindset, family relations, and sexual behavior in Tajikistan under the influence of intensive labor migration. We can identify several factors of this transformation. Firstly, it is the scale of labor migration. It is large and affects almost every family in Tajikistan. Secondly, it is the socio-demographic structure of labor migrants, among whom the majority is people of employable and reproductive age. Those mostly are men of young and middle age. In the circumstances of the conventional Tajik society, people normally marry very early (when they are 17-20 years old). In the situation when the social basis of labor migration is considerably expanding (young people become actively involved), many people postpone marriage, which results in the increase of the average marriage age in Tajikistan. Consequently, the birth rate in the country descends. Thirdly, labor migration, in its function as a social phenomenon, drastically changes the mentality of involved people, many of whom after having gained the experience of labor migration to Russia change their understanding of family relations and marriage. Many responders assimilate the Russian way of living, postpone marriage and birth of children, and take the change of sexual partners and divorce easier. Fourthly, long living apart together, which is caused by labor migration, often results in destruction of family relations and disruption of families in Tajikistan. Nearly $28 \%$ of the responders in Tajikistan are sure that disruption of a family is impossible and approximately $23 \%$ of the responders believe (Olimova \& Bosk, 2003, p. 118), however, the same percentage (namely, 26\%) of the responders believes that the disruption is possible. This is a very alarming and, what is more important, large-scale tendency-one in four responders is worried that the family can disrupt. Only one fifth part of partners in Tajikistan have never thought of this, and $23 \%$ of them believe that strength of relations is affected not so much by the distance or separation, as by other factors (relations between the spouses, the parents' experience, financial welfare, etc.). To some extent, the resultant index of the labor migration-related divorce factors' effect can be considered the replies of two groups of responders to the question about discussion of the breach in 
relations between spouses. One third part of labor migrants in Russia confirms that sometimes, such talks have taken place in their families, and in Tajikistan, it is confirmed by one in four wives (husbands). These problems have often occurred with 5\% of labor migrants polled in Russia and $4 \%$ of their spouses in Tajikistan. Fifthly, labor migration provides a person who is involved in it with certain financial independence, which together with other factors often estranges him (her) from the models of the traditional family existing in Tajikistan.

To conclude with, we would like to express our gratitude to the Russian Foundation of Fundamental Research, which supported this project (grant \# 12-06-00245-a). This work was funded by this subsidy allocated to Kazan Federal University for the state assignment in the sphere of the scientific activities.

\section{References}

Akramov, F. S. (2006). Demographic situation and labor migration from Tajikistan to Russia. The practice of attraction and utilization of expatriate workforce in Russia: Tendencies, mechanisms, technology. In the Proceedings of the 2006 Scientific and Practical Conference (pp. 128-136). Moscow.

Analysis of Institutional and Legal Frameworks and Overview of Cooperation Patterns in the Field of Counter-Trafficking in Eastern Europe and Central Asia: Research Report. (2003). IOM, Vienna.

Baizhigitov, N. (2013). Labor migration. Retrieved May 21, 2014, from http://rus.kg/news/policy/8923-pyatproblem-kyrgyzsko-kazahskih-otnosheniy.html

Data of the Central Bank of the Russian Federation. (n. d.). Retrieved May 12, 2014, from http://cbr.ru

Data of the Federal State Statistics Service. (n. d.). Retrieved May 21, 2014, from http://www.gks.ru

Export of workforce from Uzbekistan. (2003). In Z. A. Zaychonkovskaya (Ed.), In the Labor migration in the CIS: The Social and economic effects (pp. 87-116). Moscow: International Organization for Migration.

Foltz, R. (1996). The Tajiks of Uzbekistan. Central Asian Survey, 15(2), 213-216. http://dx.doi.org/10.1080/0263 4939608400946

How to organize and protect labor migrants in agriculture and related sectors. (2008). Geneva: The International Union of Employees of Food and Tobacco Industries, Agriculture, Public Catering, and Related Industries. Retrieved May 27, 2014, from http://www.fpkk.ru/text/migrantsbook.pdf

Jonson, L. (2006). In I. B. Tauris (Ed.), Tajikistan in the New Central Asia (p. 108).

Juraeva, G. (2011). Tajiks in Russia. Retrieved May 21, 2014, from http://russ.ru/Mirovaya-povestka/ Tadzhiki-v-Rossii

Karabulatova, I. S., \& Polivara, Z. V. (2013). Turkic and Slavs: Bi-polylinguism in globalization and migrations (on an example of Tumen region). Middle-East Journal of Scientific Research, 17(6), 832-836.

Kirghizstan asks for help in migration, invites Russia to Osh and the economy. (n. d.). Retrieved May 21, 2014, from http://www.migracia.ru

Labor and employment in Russia. (2011). Statistical Collection (p. 567). Moscow: Rosstat.

Migration trends in Eastern Europe and Central Asia: 2001-2002 Review (pp. 118-132). (2002). Geneva: IOM.

Monitoring of legal expatriate labor migration in the 2007-2008 period (pp. 144-256). (2009). Moscow: The Federal Migration Service.

Muslim, S. (2007). Riyadh: Maktaba Dar-us-Salam, 4, 1405. Al-Lmam Muslim.

Olimova, S., \& Bosk, I. (2003). Labor migration from Tajikistan (p. 248). Dushanbe: MOM.

Pickup, F. (2003). The Impact of Transition and the Afghanistan Crisis on Employment and Decent Work Concerns in Kyrgyzstan, Tajikistan and Uzbekistan (Vol. 13, pp. 66-74). WP, Geneva, ILO.

Ryazantsev, S. V. (2007). Labor migration in the CIS and Baltic countries: Tendencies, consequences, regulation (p. 382). Moscow: Formula Prava.

Ryazantsev, S. V. (2010). Workers from the Central Asia countries in the housing and public utilities sector of Moscow (work report). Work report (MOT): The Sub-regional Bureau for the countries of Eastern Europe and Central Asia. Moscow: MOT. Retrieved April 6, 2014, from http://www.ilo.org/public/russian/region/ eurpro/moscow/projects/migration.htm

Sayfulina, F. S., Karabulatova, I. S., Yusupov, F. Y., \& Gumerov, I. G. (2013). Contemporary issues of textual analysis of Turkic-Tatar literary monuments of Western Siberia. World Applied Sciences Journal, 27, 492-496. 
Tirmidhi, M. (2010). Al-Jami' As-Sakhih. Sunan an-Tirmidhi (p. 200). Moscow: Estern Literature.

Turdiev, T. I. (2012). Migration aspect of the stable development of Kirghizstan. In the Proceedings of the International Workshop: Migration Bridges in Eurasia (pp. 203-214). Moscow: Ekon-Inform.

Twentieth Anniversary of the Commonwealth of Independent States 1991-2010. (2011). Statistical Collection (p. 324). Moscow: Inter-governmental Statistical Committee.

Year Book on Illegal Migration, Human Smuggling and Trafficking in Central and Eastern Europe: A Survey and Analysis of Border Management and Apprehension Data from 19 States, 2004. International Centre for Migration Policy Development, Vienna.

Yoo, K. S. (2011). Korea: Country Report, Migration and the Labour Market in Asia: Recent trends and policies, Tokyo, The Japan Institute of Labour. In the Migration and Remittances Fact book 2011 (2nd ed., pp. 324-328). Washington DC: the World Bank.

Yuldashev, T. (2009). Labor migrants from Uzbekistan. Retrieved May 12, 2014, from http://www.proza.ru $/ 2009 / 06 / 03 / 933$

\section{Copyrights}

Copyright for this article is retained by the author(s), with first publication rights granted to the journal.

This is an open-access article distributed under the terms and conditions of the Creative Commons Attribution license (http://creativecommons.org/licenses/by/3.0/). 